\title{
水流による石礫粒子群の移動機構とそのモデル化 \\ MECHANISM OF STONES MOVING IN STREAMS AND THREE-DIMENSIONAL NUMERICAL MODELING
}

\author{
福田朝生 $1 \cdot$ 福岡捷二 2 - 内田龍彦 3 \\ Tomoo FUKUDA, Shoji FUKUOKA and Tatsuhiko UCHIDA \\ 1正会員 修（工）中央大学大学院工学研究科土木工学専攻（†112-8551 東京都文京区春日 1-13-27） \\ 2 フェロー 工博 Ph.D 中央大学理工学部特任教授，中央大学研究開発機構教授（同上） \\ 3 正会員 博(工) 中央大学研究開発機構准教授（同上）
}

\begin{abstract}
To understand and explain mechanism of the stones moving in streams is required for among natural and artificial environment, such as flushing bypass channel design, debris flows and sediment-laden flow in rivers. This paper deals with three-dimensional computational method for stones moving in streams taking in to account the shape of stones and mechanical interaction between stones and streams. The method is applied to a real scale experiment in concrete channel in which stones moving in streams were measured. In the case of one stone in streams, validation of the model has been checked by the experimental results. And the importance of stones shape for their moving is demonstrated by the analysis. In the case of a cloud of stones in streams, the present model seems to under-estimate the effect of moving stones and to need the improvement of the model.
\end{abstract}

Key Words : stones shape, mechanical interaction between stones and streams, large scale model test, three-dimensional numerical modeling

\section{1. 序論}

水流中の石礫粒子群の移動機構を把握することは, 石礫河川の河床変化の予測, 排砂バイパス水路を代 表とする排砂施設の設計条件の確立, 河川の環境変 化を推定する上で重要な課題となっている. 一般に 石礫河道は幅広い粒度分布を持つため, 移動機構に は，石礫間の衝突および水流と石礫粒子群の相互作 用の解明が重要である。福岡ら ${ }^{1)}$ は, 石礫粒子群の 移動機構を把握するため水路長 $45 \mathrm{~m} の$ 実寸大のコン クリート製の大型水路を用い, 水流中に粒径別に色 を付けた石碩粒子群を投入し画像解析により石碩粒 子群の軌跡を計測している（以降, 大型水路実験と 呼ぶ）。このような実寸大の石碟粒子群の水流中の 移動を実用上十分な精度で解析的に説明することが できればその結果の適用範囲は広く, 研究の持つ意 義は大きい. 本研究では, 水流中の石碩粒子群の移 動機構の理解を目的とした基礎的研究として, 石硫 粒子の運動を個々に評価するための三次元場の解析 モデルの構築を目指す.

水流中の多量の砂碟・石礫群の運動を個々に解く 解析手法では, 流体をEuler的に解き, 固体は個別 要素法 ${ }^{2)}$ を用いて解くEuler-Lagrangeカップリング 手法が多く用いられてきた。これらの手法の多くは 石礫粒子に加わる流体力は抗力係数を用いて評価さ
れている3 が，多粒子場における粒子に働く抗力は， 単一粒子で計測された抗力係数の值が妥当である根 拠は弱い。一方，計算機の計算速度の向上により， 粒子より小さなスケールで粒子の周りの流れ場を解 析し, 流体力を直接算出し, その力で物体を移動さ せる混相流場の解析手法 ${ }^{4), 5)}$ が開発されてきている. このような解析手法は, 球の抗力係数の算定に関し て，実験值と良好な一致を示しており，水流と石碩 が混合する複雑な流れ場においても石磁に働く流体 力を適切に評価できる期待は大きい. また，流体お よび石礫粒子ともに Lagrange 的に追跡する Lagrange-Lagrangeカップリングによる粒子法を用 いた解析が五十里ら ${ }^{6}$ により行われている. 五十里 らは, 本研究で対象とする大型水路実験を対象に, 摩耗に着目し，周期境界条件を用いて $10.3 \mathrm{~m}$ の計算 水路で解析を行い，実験と同様に周期的な摩耗が生 じる結果を得ている。しかし，大型水路実験では， 水路全体に亘って摩耗が進行しているが, 計算結果 は, 水路中央部において集中して摩耗が進行するこ とを報告している。この差は，解析では大型水路実 験における水路横断方向へ分散しながら流下する石 砅粒子の移動形態を十分捉えられていないことが考 えられる。

大型水路実験による石砶粒子の運動軌跡の観察よ 
り，石磻粒子自身が球と異なる多様な形状を有する ことで跳躍が複雑になり, 水路横断方向に広がりな がら流下寸ることが示されてきた。このことから， 水流中の石磁粒子の移動を解析で評価する上では, 石碟粒子の多様な形状を考慮することが重要である。 任意形状の物体のモデルとして, 接触判定の容易さ から球を連結させるモデル ${ }^{8}$ がある. 球体連結モデ ルは, 球の重なりが生じる場合, 重なり部の形状を 幾何学的に求めることが困難となり, 質量等の物体 の特性量の算定が適切に行えない場合が多い. 牛島 ら ${ }^{5}$ は，球体連結モデルにおける物体の特性量算定 における課題を踏まえ, 物体の特性量を正確に算定 することのできる四面体要素の組み合わせで任意形 状の物体を評価するモデルを用い，流体との相互干 渉場に適用している。一方, 物体と物体の接触の判 定を四面体で行うことは, 数值処理が複雑となるた め, 四面体内部に球を配置し, 球を用いて接触判定 を行っている. この手法は, 四面体要素で構成され る物体の形状を球で正確に評価するためには多くの 球要素が必要となるほか, 四面体の角部等では, 衝 突が考慮できない箇所が生じ, 物体の接触判定に誤 差が生じることとなる.

このように物体モデルは, 球体連結モデルでは質 量等の物体の特性量の算定が, 四面体要素の連結モ デルでは接触判定が課題として残るが，水流中を移 動する石礫粒子の運動にはこの両課題への対応が求 められる. 本研究では, 両課題への対応可能な物体 モデルとして, 球体連結モデルを用いる。 ここで, 球体連結モデルにおいて課題となる物体の特性量の 算定には, 数值積分操作を導入し, これらを適切に 算定可能とすることを提案している。この球体連結 モデルを石礫粒子モデルとして用い，大型水路実験 により得られた水理量と水流中の石碩粒子群の移動 の軌跡を検証材料とし, 水流及び石䃋粒子群の混合 場の力および移動を評価可能な石䃋粒子より細かい セルで流体力を評価するEuler-Lagrangeカップリン グを採用し，大型水路実験の結果の説明を試みてい る。

\section{2. 数值解析の概要}

本研究の数值解法では, 流体-粒子が混在する個 液混相場を密度が異なる混相流体として捉え, 固相 を含めた混相流体を非圧縮性流れとして解く例えば9). 一方, 石碩粒子の運動は, 形状を維持しながら移動 させる必要があるため混相流場の固相が受ける流体 力を考慮し, 剛体の運動方程式により解き, 混相流 場の固相の位置を修正する. 図-1にモデルの概要を, 以下に詳細を示す.

\section{（1）混相流場の計算 \\ a) 混相流体の基礎式}

流れ場の計算における基礎式は以下に示す混相流 場の一流体モデル9)を用い, 乱流モデルとしてスマ ゴリンスキーモデルを用いた.

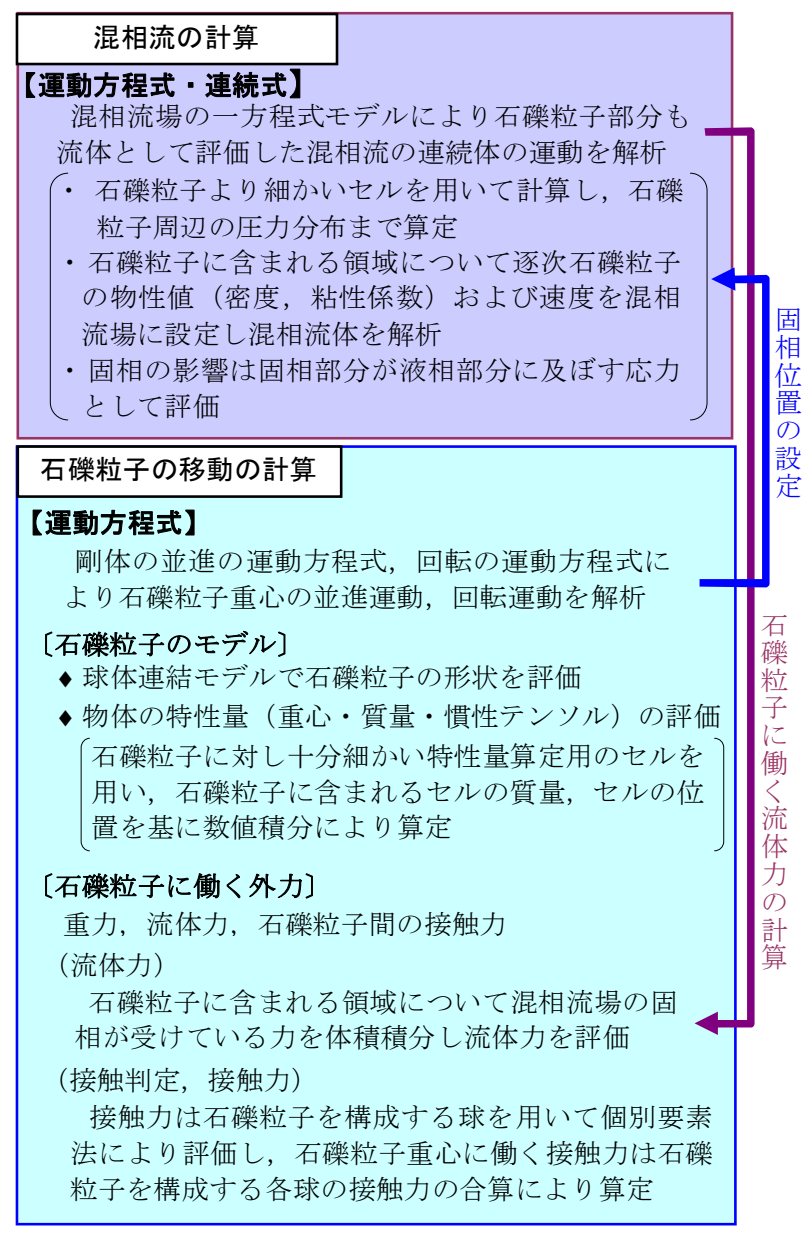

図-1 水流中の石磷粒子群の移動解析の考え方

$$
\begin{gathered}
\frac{\partial u_{i}}{\partial x_{i}}=0 \\
\frac{\partial u_{i}}{\partial t}+u_{j} \frac{\partial u_{i}}{\partial x_{j}}=F_{i}-\frac{1}{\rho} \frac{\partial P}{\partial x_{i}}+\left(v+v_{t}\right)\left(\frac{\partial^{2} u_{i}}{\partial x_{j} \partial x_{j}}\right) \\
v_{t}=\left(C_{s} \Delta\right)^{2} \sqrt{2 S_{i j} S_{i j}}, \quad v=\mu / \rho \\
S_{i j}=\frac{1}{2}\left(\frac{\partial u_{i}}{\partial x_{j}}+\frac{\partial u_{j}}{\partial x_{i}}\right) \\
\phi=\alpha \phi_{s}+(1-\alpha) \phi_{f}, \phi_{f}=f \phi_{l}+(1-f) \phi_{g} \\
u_{i}=\left\{\alpha \rho_{s} u_{s i}+(1-\alpha) \rho_{f} u_{f i}\right\} / \rho
\end{gathered}
$$

ここに， $u_{i}$ は密度で重み付計算した流体計算セル 内の $i$ 方向平均流速, $P$ : 圧力と $\mathrm{SGS}$ 応力の等方応 力成分の和, $\Delta$ : 計算格子幅, $f$ : コントロール ボリューム内の液相の占める割合 (2. (1)d d を参 照）， $\alpha$ : 流体計算セル内の気相以外の領域におけ る固相の占める割合, $\phi$ : 物性值 (密度 $\rho$, 粘性 係数 $\mu$ ）を示す. 下付の $l, s, g$ はそれぞれ液相， 固相，気相を示寸． $u_{s}$ ：固体の速度， $u_{f}$ は流体の 流速である.

連続式(1), 運動方程式(2)は, スタガード格子を 用いてSMAC法を用いて解き, 圧力の収束にはSOR法 を用いた。 


\section{b) 液相に対する固相の影響の評価}

一流体モデルであるため固相が液相に及ぼす力は 陽的には流体の基礎式には表れない，固相の運動は， 牛島 ${ }^{9)}$ と同様に, 後述する石砂粒子の運動解析に よって, 固相の流速を求め, 式(6)により流速を修 正することによって考慮される. 式(6)中の流体計 算セル地点における固体の速度 $\boldsymbol{u}_{s}$ は, 石硯粒子の 重心の並進速度 $\dot{\boldsymbol{r}}_{G}$, 石硆粒子の角速度 $\omega お$ おび重 心から流体計算セルに向かう位置ベクトル $\boldsymbol{r}_{f}$ を用 いて次式で設定する.

$$
\boldsymbol{u}_{\mathrm{s}}=\dot{\boldsymbol{r}}_{G}+\boldsymbol{\omega} \times \boldsymbol{r}_{f}
$$

\section{c) サブセル法による物性值の設定}

流体計算セルの物性值の設定（式(5)）および速度 の設定（式(6)）において用いる流体計算セル中に占 める固相の割合 $\alpha$ の算出は，流体計算セルを更に細 かく分割したサブセルを用い，石碩粒子に含まれる サブセルの数を数えて算定した.

\section{d) 水面の取り扱い}

水面の変化は, 流体計算セル中の液相の割合を密 度関数 $f$ で表し, 式(8)の密度関数 $f$ の輸送を解い て評価する.

$$
\frac{\partial f}{\partial t}+\frac{\partial f u_{i}}{\partial x_{i}}=0
$$

本研究では, 気相を含めた計算は, 圧力の収束に 時間を要するため, 気相は解かず，自由水面を計算 境界とした. 自由水面の圧力の境界条件はHirt ${ }^{10)}$ ら の手法を参考に水面を含むセルと水面内部のセルで 圧力勾配を算定した場合に水面で圧力が0になるよ うに水面を含むセルの圧力を設定した。また，式 (8) は直接計算すると水面付近において密度関数 $f$ の数值拡散が生じる. 本研究では, 拡散後の密度関 数に対し, 同一平面座標の密度関数を水路底面から 再設定し，密度関数の拡散を制御した。

\section{(2) 流体中の石礫粒子の運動の計算}

本研究における石㗂粒子の移動は, 剛体の運動方 程式 5 ,), を用いて解き, 石碟の接触判定および接触 力は, 石縜粒子を構成寸る球それぞれで個別要素法 2)を用いて評価する.

\section{a) 石礫粒子運動の基礎式}

石磕粒子の運動解析には, 剛体の並進運動に対す る方程式(9)および回転運動に対するEulerの運動方 程式 $(10)^{7}$ を用いる.

$$
\begin{gathered}
M \ddot{\boldsymbol{r}}_{G}=M \boldsymbol{g}+\boldsymbol{F}_{f}+\boldsymbol{F}_{c} \\
\dot{\boldsymbol{\omega}}_{r}=\boldsymbol{I}_{r}{ }^{-1}\left(\boldsymbol{R}^{-1} \boldsymbol{N}-\boldsymbol{\omega}_{r} \times \boldsymbol{I}_{r} \boldsymbol{\omega}_{r}\right) \quad, \quad \boldsymbol{N}=\boldsymbol{N}_{f}+\boldsymbol{N}_{c}
\end{gathered}
$$

ここに $\ddot{\boldsymbol{r}}_{G}$ : 石磎粒子の重心の加速度, 下付 $f$, $c$ は, 流体力および接触力を示し, 下付 $r$ は, 剛体 に固定された座標系の值を示す。 $\boldsymbol{R}$ ：空間座標系 から剛体に固定された座標系への座標変換のテンソ ル，I：慣性テンソルである。回転に対する運動方

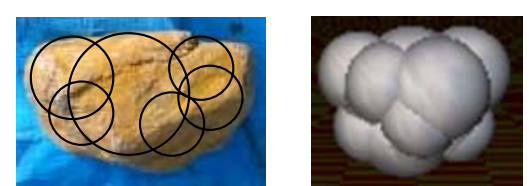

図-2 石礫粒子のモデル化

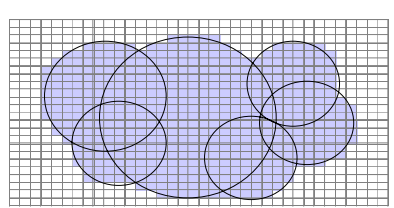

図-3 物体の特性量（体積, 慣性テンソル）算定に 用いるセル

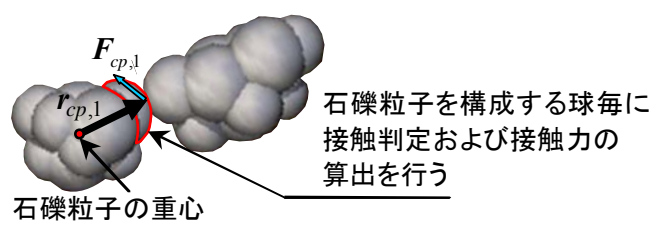

図-4 接触力の評価

程式では，剛体に固定された座標系の次時刻の角速 度 $\boldsymbol{\omega}_{r}$ を求め, 座標変換のテンソル $\boldsymbol{R}$ を用いて空間 座標の角速度 $\omega$ を求める. 角速度 $\omega$ で $\Delta t$ 時間分の 回転に相当する石㗂粒子の角度を変化させ，その角 度に対応する新しい時刻の座標変換テンソル $\boldsymbol{R}$ を 求める. 新しい時刻の石䃋粒子を構成する球の位置 は, 新しい時刻の石硆粒子の重心位置および初期の 重心位置に対する球の相対座標を基に新しい時刻の 座標変換テンソル $\boldsymbol{R}$ を用いて設定する．回転に対 する運動方程式の解法は牛島らによる文献9を参考 にし，座標変換には四元数を用いた.

b) 石礫粒子のモデル化

本研究では，石䃋粒子を剛体として扱い，剛体の 運動方程式を用いて粒子の移動を解く. 石碩粒子の 形状は石碟同士の接触判定を行うため, 図一2のよう に球を隙間が無いように重㸚合わせた球体連結モデ ルを用いた。一方，球を任意に重衫合わせて物体を 構成する場合, 重なり部分の形状を幾何学的に算出 することが煩雑となり，石碟粒子の慣性力などの評 価の際に必要となる物体の特性量である質量, 重心 位置，および慣性テンソルを算定することが課題と なる，本研究では，重なりを有する形状を適切に評 価するため，図-3に示すように粒子に対し十分細か い特性量算定用のセルを用い，球要素に含まれるセ ルの位置, 体積を基に物体の特性量を数值積分によ り算定した．移動に伴い物体の特性量は不変である ため, この操作は, 計算初期に一度だけ行えば良い。 この数值積分操作の導入により物体の特性量が適切 に評価されるため，任意に球を組み合わせることが 可能となる.

\section{c) 流体力の評価方法}

石碩粒子に加わる流体力は，牛島ら帛と同様に圧 力項, 拡散項を用いて評価し, これを石碩粒子に含 まれる範囲で体積積分し, 式(11), 式(12)で評価する. 


$$
\begin{gathered}
F_{f, i}=\int_{\Omega_{s}}\left\{\frac{\partial P}{\partial x_{i}}+\rho\left(v+v_{t}\right)\left(\frac{\partial^{2} u_{i}}{\partial x_{j} \partial x_{j}}\right)\right\} d \Omega \\
N_{f, i}=\int_{\Omega_{s}} \varepsilon_{i j k} r_{f, j}\left\{\frac{\partial P}{\partial x_{k}}+\rho\left(v+v_{t}\right)\left(\frac{\partial^{2} u_{k}}{\partial x_{l} \partial x_{l}}\right)\right\} d \Omega
\end{gathered}
$$

ここに $F_{f, i}$ はi方向の流体力, $N_{f, i}$ は流体力による トルクの $\mathrm{i}$ 方向成分, $r_{f, i}$ : 石磎粒子重心から力の作 用点に向かう位置ベクトル， $\Omega_{s}$ : 石㗂粒子に含ま れる領域， $\varepsilon_{i j k}$ : エディントンのイプシロンである.

d) 個別要素法による接触力の算出

接触力の評価は，剛体に配置した球粒子それぞれ で接触判定を行い, （図-4参照）接触力 $\boldsymbol{F}_{c p}$ を算定 し, 接触力の合力を $\boldsymbol{F}_{c}, \boldsymbol{N}_{c}$ を式(13)で求める.

$$
\boldsymbol{F}_{c}=\sum \boldsymbol{F}_{c p, n}, \quad \boldsymbol{N}_{c}=\sum \boldsymbol{r}_{c p, n} \times \boldsymbol{F}_{c p, n}
$$

ここに $\boldsymbol{r}_{c p, n}$ は石砅粒子の重心から衝突地点に向かう ベクトル，下付の $n$ は衝突地点の別を示す.

粒子間の接触力 $\boldsymbol{F}_{c p, n}$ の算定は, 個別要素法により 行い, バネ定数 $k$, ダッシュポットの定数 $c$ は, 次 の式で算出した ${ }^{11)}$.

$$
\begin{gathered}
k_{n}=\left\{\frac{4}{9}\left(\frac{r_{1} r_{2}}{r_{1}+r_{2}}\right)\left(\frac{E}{1-p o s^{2}}\right)^{2} e_{n}\right\}^{\frac{1}{3}} \\
s_{0}=\frac{k_{s}}{k_{n}}=\frac{1}{2(1+p o s)} \\
c_{n}=2 h \sqrt{\frac{m_{1} m_{2}}{m_{1}+m_{2}} k_{n}} ; c_{s}=c_{n} \sqrt{s_{0}}
\end{gathered}
$$

ここに下付添え字 $n$ は球の中心から接触点に向か う方向の成分を， $s$ は接平面上の直交する2方向を 示すものとする. $r_{1}, r_{2}$ : 接触する球の半径, $m_{1}$, $m_{2}$ : 接触する球の質量である.

\section{3. 大型水路実験結果 ${ }^{1)}$ を対象とした計算}

\section{(1) 計算条件}

図-5に計算水路諸元を, 図-6に水路横断形状を示 す. 計算に用いる水路は, 大型水路実験の諸元を基

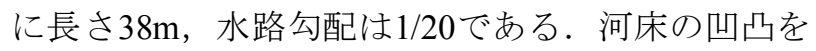
設定するため, 水路の底面は球により構成し, 球の 半径を $0.02 \mathrm{~m}$ の範囲で乱数を用いて変化させている. 図-7に設定した水路を示す。計算における座標系は デカルト座標系とし, 流下方向をx軸とし, 水路底 面に垂直な方向を $\mathrm{z}$ 軸とした。計算の安定のため, 水路上流と下流に池を設定し，境界条件には，上流 端は，実験と同様に $0.5 \mathrm{~m}^{3} / \mathrm{s}$ に一致するように一様流 速を与え，下流端は圧力 0 を与えた。 石礫群の計算 において投入する石䃇の粒度分布を図-8に示す。石 礫粒子は，図-9に示す $8 \sim 9$ 個の球で構成した4種類 の実際に用いた石碩形に近似した形状の石磁を実験 の粒度分布に一致させて水路に投入した。石䃋径は 同一体積の球の直径で定義した。石碩粒子群の投入
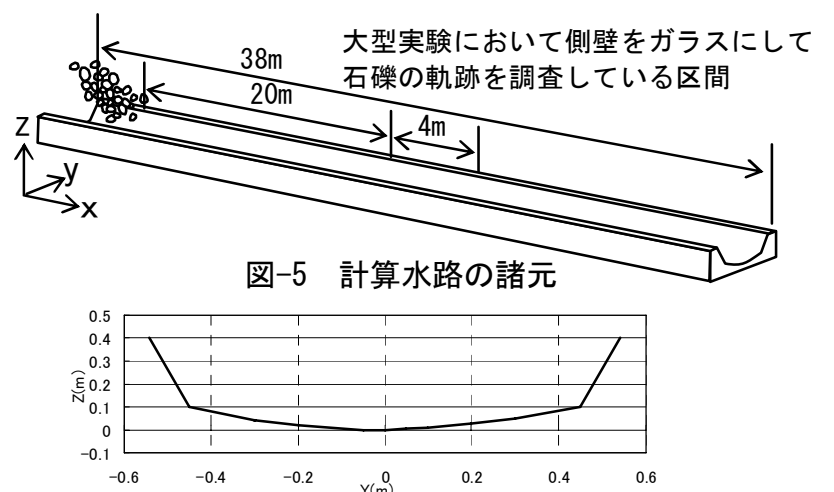

図-6 計算水路横断図

\begin{tabular}{|c|c|c|}
\hline 項目 & 值 & \begin{tabular}{|l|} 
単位 \\
\end{tabular} \\
\hline $\begin{array}{l}\Delta x, \Delta y, \Delta z \\
\text { :流体計算セル幅 }\end{array}$ & 0.02 & $\overline{\mathrm{m}}$ \\
\hline 流体計算セル数 $(2,000(\mathrm{x}) \times 64(\mathrm{y}) \times 50(\mathrm{z}))$ & $6,400,000$ & セル \\
\hline サブセルの幅 & 0.01 & $\mathrm{~m}$ \\
\hline$\Delta t \quad$ :流体計算時間ステップ & $1.0 \times 10^{-4}$ & $\mathrm{~s}$ \\
\hline \begin{tabular}{|l}
$\rho_{w}$ \\
:水の密度 \\
\end{tabular} & 1,000 & $\mathrm{~kg} / \mathrm{m}^{3}$ \\
\hline \begin{tabular}{|ll}
$\rho_{s}$ & :礫の密度 \\
\end{tabular} & 2,650 & $\mathrm{~kg} / \mathrm{m}^{3}$ \\
\hline$\mu_{w} \quad$ :水の粘性係数 & $8.9 \times 10^{-4}$ & $\mathrm{~Pa} \cdot \mathrm{s}$ \\
\hline$\mu_{s} \quad$ :礫の粘性係数 & $8.9 \times 10^{-4}$ & $\mathrm{~Pa} \cdot \mathrm{s}$ \\
\hline$C_{s}$ : :スマゴリンスキー定数 & 0.173 & - \\
\hline 物体の特性量算定に用いた計算セル幅 & 0.001 & $\mathrm{~m}$ \\
\hline$\Delta t^{\prime} \quad$ :個別要素法計算時間ステップ & $1.0 \times 10^{-6}$ & $\mathrm{~s}$ \\
\hline$E$ :弾性係数 & $5.0 \times 10^{10}$ & $\mathrm{~Pa}$ \\
\hline pos : ポアソン比 & 0.33 & - \\
\hline$h$ :ダッシュポットの係数 & 0.11 & - \\
\hline$\kappa$ : 動摩擦係数 & 0.5 & - \\
\hline
\end{tabular}

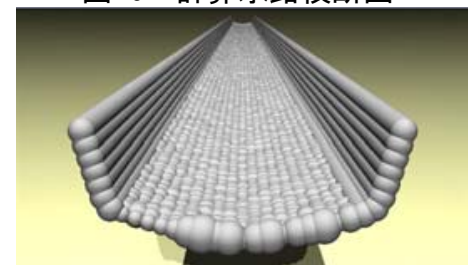

図-7 計算水路全景

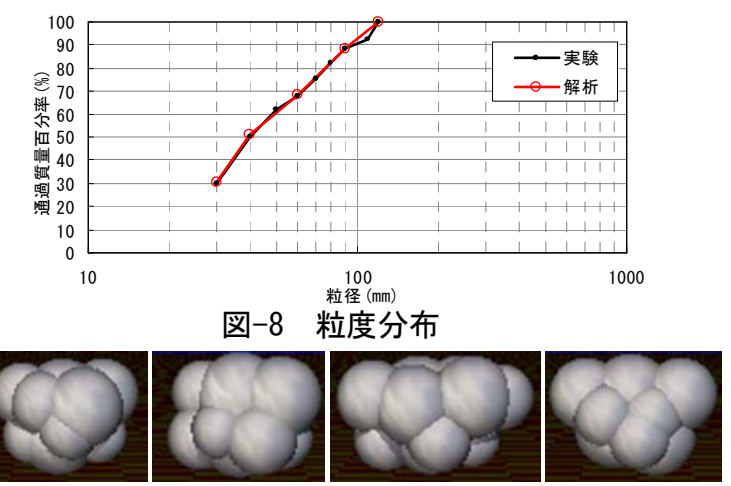

図-9＼cjkstart水路に投入した石砂粒子の形状

表-1 計算に用いた定数

量は，実験と同様に $360 \mathrm{~kg}$ を秒間で投入した。また， 大型水路実験では, 群として流れる石礫の軌跡の他, 単一粒子を流下させた場合の軌跡についても計測し ている. 本研究では, 単一粒子の実験における石碩 粒子の軌跡を検証材料とし，形状を考慮した石碩の モデル(図-9左端の形状) と球を投入した計算を行い, 形状の影響を比較した。計算で用いた定数を表-1に 示す.

\section{(2) 計算結果}

\section{a) 単一粒子による計算結果}

単一粒子の計算において，形状を考慮した石碩粒 子モデルおよび石碩の単一径に相当する球の計算結 


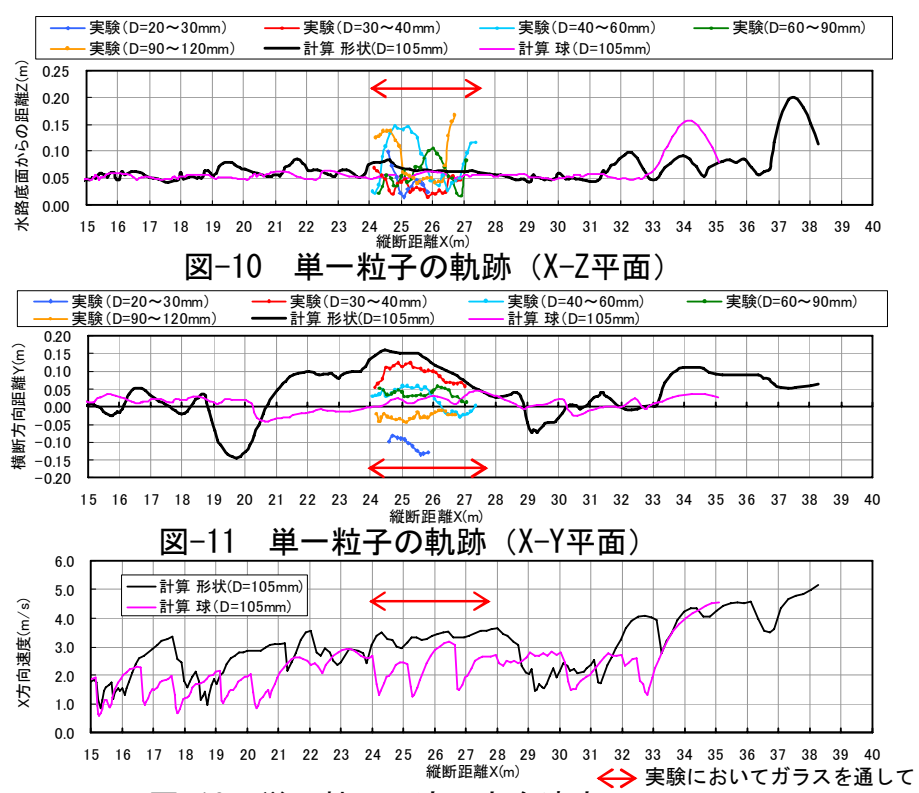

図-12 単一粒子の流下方向速度 軌跡を調查した区間

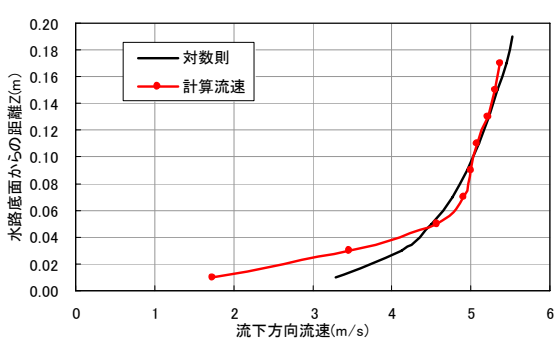

図-13＼cjkstart調査地点の流速分布

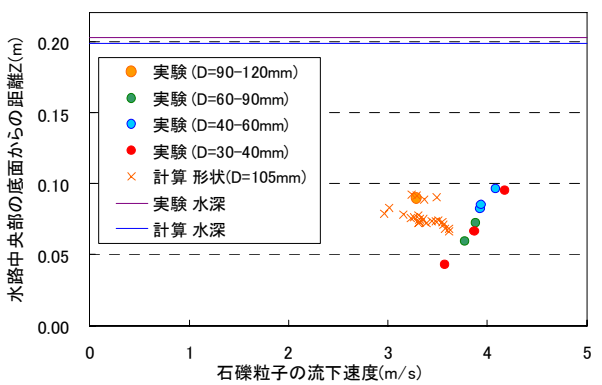

図-14 石碟粒子の流下方向速度
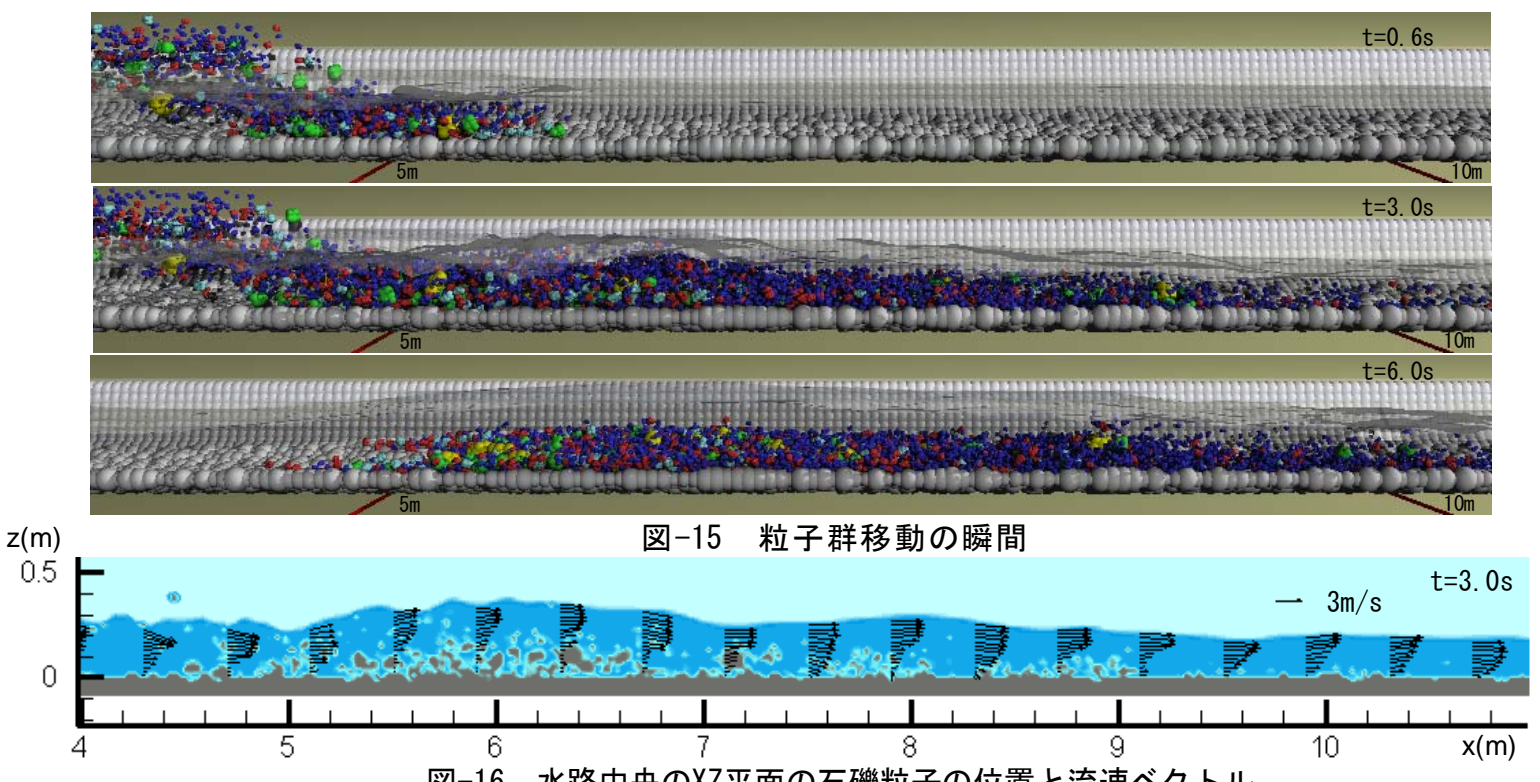

図-16 水路中央のXZ平面の石礫粒子の位置と流速ベクトル

果より得られた軌跡をXZ平面，XY平面に示したも のを図-10, 図-11に示す。図中には大型水路実験に より得られた単一粒子の軌跡を合わせて示した。

図-12に流下方向距離と流下速度の関係を，図-13に， $28 \mathrm{~m}$ 地点の石碟粒子通過時の流速分布を示す. 図13より本計算では，底面付近では，対数則より流速 がやや小さく評価されている。図-10より，形状を 考慮した石碩粒子の跳躍高さは，大型水路実験の軌 跡を調査している区間では実験と比較しやや小さい ものの，それより下流で同程度の跳躍高さとなって いる．形状を考慮した粒子は，実験結果と同様に大 部分の時間において跳躍しているが, 球では, 跳躍 している時間は短い。これは，石碟粒子の方が同一 体積の球と比較した場合, 流体中の投影面積が大き く, 流体力を受けやすいことや, 粒子形状に凹凸が あるため, 衝突によって回転運動を並進運動に変化 させ跳躍するためと考えられる. 図-11に示す平面 的な軌跡に関しては，実験では，水路幅全体に亘り，
石礫が流下している軌跡が得られている．形状を考 慮した粒子は，実験と同様に水路を幅広く流下して いるのに対し, 球では, 水路中央部しか流下出来て おらず，石磒粒子の軌跡を詳細に捉えるためには， 石礫粒子の形状を考慮する必要があることを示して いる。図-14は調査区間を流下する間の0.05秒毎の 形状を考慮した石碩粒子の水路底面からの高さと流 下方向速度の計算結果を示す. 形状を考慮した石礫 粒子の流下速度は，実験結果と良く一致している.

b) 石磁粒子群による計算結果

石碩粒子群の状況と移動の瞬間計算像を図-15に, 3秒後の水路中央における石碩粒子群の位置と流速 ベクトル，水面高さを図-16に示す。石碩粒子群が 大量に投入され，水流と石礫粒子群が激しく混合す る場においても本計算モデルは安定した計算を可能 にしている．実験では，投入から20秒後には，大部 分の石礫粒子が調査区間を流下しているのに対し, 計算では, 投入地点の石碟堆積部直下流付近から石 


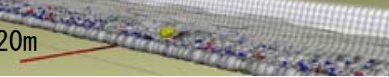

図-17 石礫粒子群の流下の状況（ $\mathrm{t}=22 \mathrm{~s} ）$

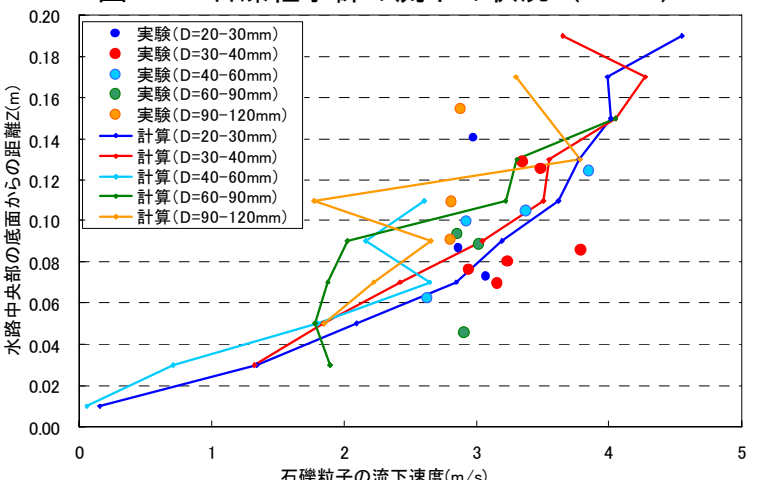

図-18 石礫粒子群の流下速度
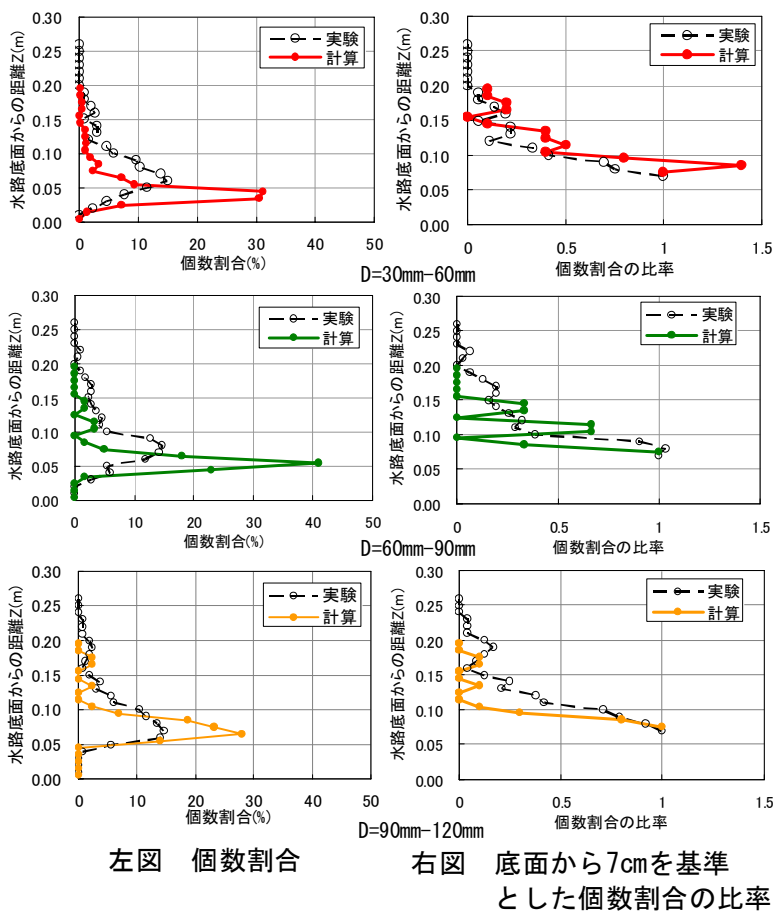

図-19 個数割合の鉛直分布の比較

礫粒子は流下していくもののその量は少なく，22秒 後においても上流域の堆積石礫が残っている（図一 17参照）。この要因として，底面付近のセル幅がや や粗いことなどが考えられ，モデルの改良を進める 必要がある。

実験と比較し，流下している石礫粒子群の濃度が 小さい課題を残しているが，移動した石礫粒子群に 着目し，投入地点から $20 \mathrm{~m} \sim 24 \mathrm{~m}$ の区間を通過して いる石礫について，実験データとの比較を行った。 石礫粒子群の速度の鉛直分布について計算と実験結 果の比較を図-18に示す。計算石碩粒子の速度は, 跳躍している水路上部で実験值に近い值を示してい る. 一方, 水路底面では実験と比較し速度が遅い。 粒子の鉛直個数分布について計算と実験との比較を 図-19に示す. 大型水路実験では, 水路底面付近の 粒子群の運動は可視化できない水路構造のために, 見積もりが不能であった。このため，底面付近では
粒子軌跡データは十分捉えられていない. そのため, 実験においてデータが多くとられている水路底面か ら $7 \mathrm{~cm}$ 高さの粒子数を基準とし，それより上部の 個数割合を $7 \mathrm{~cm}$ 地点からの比率で評価し計算值と実 験值の比較を行った. 個数割合の比率は, $90 \mathrm{~mm}$ 以 上の粒径でやや上層部の割合が小さいものの計算結 果は実験值に近い值となっている.

\section{4. 結論と今後の課題}

本研究では，石礫粒子形状を評価できるモデルを 用い, 水流と石砅粒子群が相互干渉し, 流下する3 次元場の解析モデルを構築した。本モデルは, 単一 粒子が水路を流下する場について，大型水路実験結 果の石䃯粒子の軌跡を説明することが出来，石礫粒 子の移動を把握するためには，粒子形状を考察する ことが重要であることを示した．多粒子からなる石 碩群の移動の解析では, 水流が石砶粒子群を流下さ せる効果を小さく見積もっており，モデルの改良が 課題である.今後は, 開発したモデルの精度向上を 図り，粒度分布および石碩形状が水流中の石碩粒子 群の移動機構に及ぼす影響について検討し，河床付 近を移動する流砂の力学解明につなげたいと考えて いる。

\section{参考文献}

1）福岡捷二, 渡邊明英, 篠原康宽, 山下翔, 斉藤一正 : 高速で多量に流下寸る礫群の運動機構と床面摩耗量の 推算，河川技術論文集，第 11 巻, pp.291-296, 2005.

2) Cundall,P.A., Strack,O.D.L., : A discrete numerical model for granular assemblies, Geotechnique, Vol.29, No.1, pp.47-65, 1979.

3) 例えば，後藤仁志，Abbas Yeganeh-Bakhtlary，酒井哲 郎 : 混相流モデルと個別要素法の誘導による高濃度掃 流層の数值解析, 土木学会論文集 No.649/ II -51, pp.17-26, 2000.

4) 梶島岳夫, 瀧口智志, 浜崎洋至, 三宅裕 : 渦放出を伴 う粒子を含む鉛直平行平板間の乱流構造, 日本機械学 会論文集（B 編），第 66 巻，pp.120-127，2000.

5) 牛島省, 福谷彰, 牧野統師 : 3 次元自由水面流中の接 触を伴う任意形状物体運動に対する数值解法, 土木学 会論文集 B， Vol No.2，pp.128-138，2008.

6) 五十里洋行, 後藤仁志, 酒井哲郎 : 固液混相流型粒子 法による排砂水路底面の摩耗過程のシミュレーション, 水工学論文集, 第 51 巻, pp.853-858, 2007.

7) 例えば，大熊政明 : 新・工業力学 例題から応用への 展開 数理工学社, 2005

8) 例えば, 松島亘志, 竿本英貴 : 複雑な砂粒子形状の個 別要素モデル化手法の提案, 地盤工学研究発表会 発 表講演集,Vol. JGS37， pp.357-358， 2002.

9) 牛島省, 福谷彰, 藤岡奨, 禰津家久 : 3 次元流体中を 移動する任意形状物体の数值解法, 水工学論文集, 第 51 巻, pp.847-852, 2007.

10) Hirt,C.W. Nichols ,B.D. : Volume of Fluid(VOF)Method for the Dynamics of Free Boundaries, J.Comput.Phys., 39, pp.201-225, 1981.

11) 後藤仁志 : 数值流砂水理学 森北出版, 2004

(2011. 9. 30受付) 